NBER WORKING PAPER SERIES

\title{
QUALITY CERTIFICATION AND THE ECONOMICS OF CONTRACT SOFTWARE \\ DEVELOPMENT: A STUDY OF THE INDIAN SOFTWARE INDUSTRY
}

\author{
Ashish Arora \\ Jai Asundi \\ Working Paper 7260 \\ http://www.nber.org/papers/w7260
NATIONAL BUREAU OF ECONOMIC RESEARCH 1050 Massachusetts Avenue
Cambridge, MA 02138
July 1999

We are grateful to V.S. Arunachalam for advice and encouragement, and to S. Raghavan, V.A. Sastry, Bankim Shah, and Sunil Wadhwani for sharing their insights about the software industry with us. Ronnie Fernandes, Robert Cole, David Levine, and participants at the NBER workshop on Organizational Performance, April 1999 provided helpful comments and suggestions on an earlier draft. Zhaoli Rong, Hairong He and Kushal Choksi provided competent research assistance. We gratefully acknowledge support from a grant from the Alfred P. Sloan Foundation. The views expressed herein are those of the authors and not necessarily those of the National Bureau of Economic Research.

(C) 1999 by Ashish Arora and Jai Asundi. All rights reserved. Short sections of text, not to exceed two paragraphs, may be quoted without explicit permission provided that full credit, including (C) notice, is given 
to the source.

Quality Certification and the Economics of Contract Software

Development: A Study of the Indian Software Industry

Ashish Arora and Jai Asundi

NBER Working Paper No. 7260

July 1999

\begin{abstract}
A significant amount of software development is being outsourced to countries such as India. Many Indian software firms have applied for and received quality certifications like the ISO9001, and the number of quality certified software firms has steadily increased. Despite its growing popularity among Indian software developers, there is very little systematic evidence on the relationship of ISO certification to organizational performance. Using data on 95 Indian software firms and their US clients, we develop a stylized model of a firm that develops software for others to articulate the different ways in which ISO certification can affect firm profits. We conclude that ISO certification enhances firm growth. The results provide partial support for the proposition that ISO certification also enhances revenue for a given size, suggesting that firms are receiving a higher price per unit of output. In turn, this is consistent with the notion that ISO certification also enhances the quality of output. Our field studies confirm that although most firms see ISO certification as a marketing ploy, some of them do proceed to institute more systematic and better-defined processes for software development.
\end{abstract}

Ashish Arora

Heinz School

Carnegie Mellon University

Pittsburgh, PA 15213

ashish@andrew.cmu.edu
Jai Asundi

Engineering and Public Policy

Carnegie Mellon University

Pittsburgh, PA 15213

asundi@andrew.cmu.edu 


\section{Introduction:}

The rapid growth of the computer software industry in India in recent years has attracted a great deal of attention. Revenues and employment in the industry have been , growing at $50 \%$ per year for the past four or five years, and exports account for over two thirds of the revenues. Despite the rapid growth, the industry is small by international standards, with sales of $\$ 3.8$ billion in 1998-99 compared with the estimated world software market of $\$ 300-500$ billion. Most of the services provided consist of developing and maintaining software for others -- staff augmentation services (supplying programmers), software services such as data conversion, porting, year 2000 remediation and maintenance, and development of software applications and tools.

Abundant supplies of educated labor and low wages, along with excess demand for IT professionals in developed countries, have been largely responsible for the sustained increase in exports. However, a steady $15 \%-25 \%$ growth in the wages of Indian software professionals threatens to undercut the cost advantage. The software industry association has responded by stressing the need to improve the software development processes used by Indian software firms and is actively encouraging firms to get quality certified. The government also provides incentives to firms with such certifications.

The most popular quality certification in India is the ISO9001 of the International Standards Organization (Radice, 1995). A few firms have also opted for a quality certification process developed specifically for software called CMM - Capability Maturity Model (Paulk et. al., 1993). Although the benefits of quality certification are sometimes taken as axiomatic, there is very limited evidence on this issue. ' In this paper we develop and estimate a simple model of the software service industry to explore systematically the different ways in which ISO 9001 (ISO henceforth) certification affects firm performance. We distinguish between the quality-increasing role of ISO certification from the signaling role, and estimate the relative significance of each using. In so doing, we recognize that firms choose to get ISO certified, and that principle, ISO

\footnotetext{
${ }^{1}$ Case studies at Hughes (Humphrey et al., 1991) and Raytheon (Dion, 1993) appear to show that adopting methodologies for process improvements yields economic benefits. Herbsleb et. al. (1997) have argued, based on responses from users, that CMM based process improvements lead to better project management at organizations. However, there does not exist any systematic study of this issue (Slaughter et. al., 1998).
} 
certification itself is "endogenous".

The econometric analysis, based on a sample of 95 Indian software firms, is complemented with site visits and interviews with more than 20 Indian software firms , and 12 of their US based clients. As well, we have had informal discussions with management and quality consultants in India and the US. The field research, described in more detail in the appendix, informs our analysis in two ways. First, we use it to develop a stylized model of a software service firm in India and to help ground some of the critical assumptions of the model. Second, we use them as an informal check of the empirical results. Therefore, although this paper is about the effect of quality certification in software, our hope is this research will also inform future studies of the economics of the software services industry. As well, this research links to the literature on how firms from developing countries acquire technological capability and to the literature on the international division of labor in the so called "high tech" industries.

We begin by describing the major types of quality certification for software developers, and some issues in the measurement of software productivity, and quality certification in section 2. The next section introduces the Indian software industry, which motivates our formal model in section 4 . We discuss our empirical methodology and the issues regarding measurement and data sources in section 5. Section 6 discusses the empirical results and their implications. Section 7 summarizes our main findings and concludes.

\section{Software Quality: Measurement, Metrics and Certifications}

In software, defining quality standards is itself particularly difficult, because most software development projects involve design activity by human beings. The difficulty of measuring output quality for complex software systems has led to a strong emphasis on process. The implicit assumption, certainly in software quality programs but also in most other quality programs, is that better-defined and documented processes lead to a better product. In 1987, the International Standards Organization (ISO) developed a framework for production standards, the ISO9000 series, which has since been adapted to software development. ${ }^{2}$ Around the same time, the Software Engineering Institute (SEI)

\footnotetext{
${ }^{2} \mathrm{~A}$ British guide for applying ISO 9001 to software, TickIT, provides stricter guidelines and imposes strong
} 
developed a framework called the Capability Maturity Model (CMM), aimed initially at firms developing large software systems for the US Department of Defense. This model, which has since diffused more broadly, has five levels of increasing "maturity" of the , software development processes and organization.

The Waterfall Model (Fig. 1) is a popular software development framework that underpins both CMM and ISO9001 for software ${ }^{3}$. The software development process is divided into the following sequential parts: requirements analysis, high level design, low level design, coding, testing and post-production support. Within each, there are established sets of software engineering practices. The establishment of these processes and a method measuring them for process improvement is the essence of a quality program.

ISO9000 standards emerged out of EU guidelines for two party contractual situations. The fundamental idea of ISO 9000 standards was to ensure buyers of goods and services, by ensuring that the seller is using and adhering to consistent process standards. Thus, ISO certification essentially requires that the firm have well defined processes that it follows, and that this is well enough documented that an external auditor can verify both that the processes are documented and that the company adheres to the processes. ${ }^{4}$ Indeed, the ISO methodology has been described as "document what you do, do what you document, and verify that you are doing it" (unnamed manager quoted in Cole 1999: 156).

ISO standards have since become widely adopted as a quality standard, almost to the exclusion of other, arguably more comprehensive and rigorous, quality standards such as the Baldridge Award in the US (Cole 1999). This popularity of ISO is despite that (or as Cole argues, perhaps because) ISO standards do not prescribe processes that must be followed. The intent of ISO standards is to minimize variations in quality, rather than necessarily to increase quality. Similar sentiments were expressed by a manager at a large Delhi based Indian software firm, who pointed out that ISO standards meant that one could consistently produce low quality products.

\footnotetext{
training and auditor requirements than ISO9001 alone.

${ }^{3}$ An alternate model of software development is the Spiral Model (Boehm, 1981).

${ }^{4}$ In practice, sub-units of the firm (such as a software development center in one city) can be certified.

Typically however, the other sub-units get certified soon after. Our data do not permit a disaggregation
} 
By contrast, the CMM model is both specific to software and prescribes standards in different stages of software development that firms at a given level of maturity must have. ${ }^{5}$ Industry experts we interviewed believe that ISO certification roughly corresponds to maturity level two in the CMM model. Maturity level two requires that necessary process discipline be in place to repeat earlier successes on projects with similar applications. Companies assessed at this maturity level are supposed to have established basic project management processes to track cost, schedule, and functionality. The ISO9001 standard does require some elements of CMM level three, which requires that the organization have well-defined and documented processes for software development, that allow it to manage software development. ${ }^{6}$ Consistent with this, we find that although many Indian software companies have ISO9001 alone, and some have added TickIT or CMM level three or higher, very few have the latter but not ISO. The relatively small number of CMM certifications up until 1997-98 means that we shall focus only on ISO certification in this study. Future research may fruitfully compare the difference between CMM and ISO certification in terms of economic impact.

\subsection{Measurement and Metrics}

Software output has traditionally been measured through source lines of code (SLOC). However, the development of high-level languages and progress in software technologies have reduced the usefulness of this measure (Boehm, 1987). This measure capture differences in the complexity of software code and the proliferation of newer languages and coding paradigms where several languages are used within the same project complicates matters further.?

\footnotetext{
finer than the level of the firm.

${ }^{5}$ The initial ISO certificate is valid for two years, after which another external audit must be passed to keep the certification. There is no reassessment provision in CMM certification. There are other differences between ISO9001 and CMM certification procedures and requirements that are discussed in Paulk (194) and Radice (1995).

${ }^{6}$ A manager at a large Bombay based firm believed that for continuous improvement, the SEI's CMM is a better program. Managers at other firms that had an ongoing quality program shared these views.

${ }^{7}$ Other measures address these concerns but are very difficult and expensive to collect. For instance, Albrecht and Gaffney (1983) have proposed the use of Function Points (FPs). This is designed to size a system in terms of its delivered functionality, measured in terms of objects such as the numbers of inputs, outputs and files. Each of these objects is assigned a weight depending on the object complexity and importance. Measures for complexity include McCabe's cyclomatic complexity (McCabe, 1976) and Halstead's complexity measure (Halstead, 1977). The FP measure is independent of programming language
} 
Directly measuring software output requires very detailed project level data that Indian firms rarely collect and even such measures can be very subjective. We take a different approach here. In a competitive industry, all productivity improveménts must eventually be reflected in economic outcomes. Objective data and our field interviews strongly suggest that the Indian software industry is competitive and that firms are reasonably homogenous in terms of the output - contract software development and supplying programmers on a temporary basis. Thus, in this study, we use firm level outcome variables, specifically, revenues and employment. We develop a model that helps us link these variables with the unobserved changes in firm profits.

\section{The Indian Software Industry}

Most of the Indian firms are small and young, and are involved almost exclusively in software development. The median firm size in 1997, measured as number of software professionals, is 70 whereas the largest firm employed about 9000 professionals. The median age of our sample of firms is approximately the same as that of firms in the industry. However, the median size of the firms in our sample is 200 , and the median revenue of firms in our sample is twice as large as the industry median.

Few firms develop packaged software products on any substantial scale; most provide software services that are not very specialized or exclusive. ${ }^{8}$ Most firms have evolved from doing maintenance of legacy systems to lower end software development services, like low-level design and coding of software components. With some exceptions, advertising, intellectual property rights, and standards related issues are less important than for packaged software. Skilled labor is the main input and firms recruit from national or regional labor pools. In other words, there is likely to be much greater homogeneity in the type of work performed and the capabilities of firms (given size and age) than one might find in other industries.

and can used at the requirements specification stage to size and cost the software (Jalote, 1991). However, the measure of function points is subjective and estimating the total function points for large and complex systems is very difficult. Most Indian firms do not collect such data.

${ }^{8}$ It appears that firms established in 1997 or 1998 are relatively more likely to enter niche markets for specialized services, or to develop products. These firms are not in our sample. 
Exports account for about 2/3rd of industry revenues, with the US accounting for more than $50 \%$ of the export revenue. Professional services, consultancy, and data services account for about $85 \%$ of exports. In a typical export project, the clients provide, the vendor (the Indian software firm) with the functional specifications of the applications to be developed. The Indian firm does not participate in the early stages of conceptualization and high-level design. In addition to software code writing, Indian firms also carry out testing, except for acceptance testing, which the client or the final customer carries out. There are very few instances where an Indian software firm has been entrusted with requirement specification. In recent years, year 2000 projects (Y2K), typically for small applications, have formed a substantial part of exports, although these projects often also involve porting and re-engineering - recoding the application so that it can run on a Unix or Windows platform. Such work, although it can be complicated and time consuming, does not require new functionality, and does not require repeated and detailed interaction with the users.

Sometimes what are called software exports involves "bodyshopping", in which the Indian software firm largely provides software programmers and analysts on a temporary basis to the client. The key distinction is that these professionals work at the client's site (onsite) under the management and supervision of the client, and the Indian firm does little more than act as a temporary staffing agency. Regular export projects also involve a mix of onsite and offshore work, but are managed by the Indian firm rather than by the client. Few firms want to publicly disclose the extent of their onsite operations, and fewer still want to be known as a "bodyshopper". Yet industry estimates suggest that over $70 \%$ of the revenues may be from onsite work, with an unknown percentage from pure bodyshopping activity.

The distinction between offshore and onsite work is important because billing rates and profitability differ considerably between the two. Our interviews suggest that one man-year of onsite work is billed at about $\$ 90,000-\$ 100,000$ while comparable offshore work is billed at $\$ 30,000-\$ 35,000$. The bulk of the difference is accounted for by the higher cost of living in the US, as well as greater overhead and communication costs. Interestingly enough, offshore work is widely believed to be more profitable for the vendor. However, there are some important limits to the extent of offshore work. 
One is the need for face to face communication. Another has to do with incentives: Since many projects involve cost plus contracts ("time and materials" is the term widely used in the industry), clients have to trust the supplier to not overcharge them (Gopal, 1996; Bannerjee and Duflo, 1998). The problem need not simply involve shirking by the vendor: The supplier's inability to manage the software development without close supervision may be as important a problem. Although fixed price contracts would, in principle, provide the supplier with the right incentives, many software development projects have fluid requirements that change with time. ${ }^{9}$ Thus, even fixed price contracts can have important elements of time and material contracts. ${ }^{10}$

\section{Adoption of ISO 9001 by Indian SW firms}

Table 1 shows that the number of ISO certified firms has grown steadily in recent years. The popularity of ISO, however, is not confined to Indian software firms; ISO, despite its shortcomings, appears to have become the de facto "check box" standard for quality in a variety of industries worldwide. Cole (1999: 156) attributes this popularity in part precisely to the features that make ISO standards insufficient, in the eyes of many, to ensure sustained quality improvement: The simplicity of obtaining ISO certification, which reduces the uncertainties and makes the costs and benefits more predictable and uncertain (relative to other quality programs). Moreover, the popularity of ISO certification has fed on itself, attracting a large number of consultants that help firms gain certification, as well as the widespread acceptance by potential customers.

Although conventionally quality certification has been thought of as improving the quality of software produced, in the Indian context, its role in signaling to potential customers may be equally or more important. Some of the managers we interviewed believed (possibly incorrectly) that ISO certification was mandatory for doing business in Europe. One of the firms had apparently been warned by a major European customer in 1993 that ISO certification would be required by 1995. More generally, Indian firms see ISO certification as a marketing tool and a way of distinguishing themselves from the

\footnotetext{
${ }^{9}$ For instance, a Y2K project may later evolve into a porting project. A porting project may also involve enhancements or new functionality. Many projects involve on-going maintenance and support.

${ }^{10}$ In a fixed-fee contract, the deliverables as well as the deadline for the project is decided. The contract may include penalty clauses for late delivery and for poor quality. In a time-and-materials contract, the
} 
pack. Cole (1999: 153-4) notes that such motives are typical of firms going in for ISO 9000 certification, and especially small or new companies. In many developing countries, multinationals have put pressure on their suppliers and the local governments , have provided a variety of inducements to their firms to acquire certification (Cole, 1999). The Indian government has granted special subsidies and licenses to firms that obtain ISO or similar quality certifications. The National Association for Software Service Companies (NASSCOM), an Indian trade organization, has a self-proclaimed aim of persuading all firms with more than 10 employees to get certified by the year 2000.

The notion that ISO serves as a signal to attract potential customers was further supported by a top NASSCOM official, who told us that many firms looking to outsource to India ask for a list of the top 20-25 of the largest firms plus all other firms that are quality certified. One of the managers we interviewed put the signaling argument in very clear terms.

Imagine a customer is approached by a few vendors. Some have certification and some have no certification. Who will miss the chance in the first place? ... Also imagine a case where the vendor is a local company or it is an Indian or European company having (sic) an office in USA. In the first place, we will lose, as we do not have any office in USA. The customer wants some confidence of closeness to the vendor (with) whom they can speak to face to face. Over the net one can develop software and one can use the software, but selling confidence over the net can happen only for large companies who have established them for years with good work in the international market. (manager of a small firm, Bangalore, not certified but seeking certification.)

However, another manager disagreed somewhat with this view.

Clients in the US rarely ever ask for certification. ... In Europe, we see ISO certification as a tick mark in your favour but the absence of it doesn't shut you out.

(manager of small firm, Hyderabad, not certified, not seeking certification)

A manager of a large, certified firm first talked about how the clients required such certification, and only then talked about the other benefits.

Most (of our) customers like airline and auto parts companies are nowadays asking for better quality of service/product for their systems. Many of our clients have sophisticated quality assurance programs and it becomes important for us to be able to deliver quality software products and service. ... Bonus clauses are typically incorporated in project contracts and these are won through higher quality and timely deliveries of software services. ...

(Manager, large Bombay based firm, ISO and CMM certified.).

client pays on a man-hour basis. The project team size is decided in consultation with the client. 
Bannerjee and Duflo (1998) find that a firm's reputation, as measured by its age, improves the negotiating position of the Indian software firm vis a vis their overseas clients. Many of the firms that we interviewed in India said that a key element of their strategy for convincing clients to give them business was to emphasize their software development processes and methodologies. This emphasis is also evident from the content of their publicity material and websites: Virtually every firm emphasized the quality of its software methodology and those that are quality certified prominently advertise the fact.

Even though the ISO standards are generic and non-prescriptive, as a manager pointed out, it is likely that the mere fact of defining, standardizing and documenting their software processes will help firms focus on variables that are important for improving quality. According to a manager at a large Bombay based firm, most Indian firms follow a typical procedure to attain a quality certification. They first develop a set of processes, based on the ISO standards. These processes are documented and adhered to by projects within the organization while delivering software services. Once processes are stabilized, an independent auditing organization is called in to audit the company's processes and certify adherence to ISO guidelines. Our sense is that quality certification requires some effort by the firm in defining and formalizing its software development processes and methodologies. ${ }^{11}$

Moreover, even though a firm could adopt any process, ISO certification provides an opportunity to seek out and adopt software development processes that conform to established "good practices". For some firms at least, ISO certification is the first step in an ongoing commitment to quality. A very large fraction of Indian software firms that have obtained TickIT or CMM certification, first obtained ISO 9001 certification. In other words, regardless of the actual content of ISO certification, one might plausibly suspect that such certification can have real benefits in the form of enhanced quality. In the next section we develop a formal model that helps isolate the testable implications of these different effects.

\footnotetext{
${ }^{11}$ This points to another reason why statistically measuring the impact of adoption of a quality program (as opposed to certification) is likely to be difficult - simply put, the quality program may be in place for some time before certification is observed.
} 


\section{Testable implications of the impact of quality certification on performance}

Typically, in the economics literature on industrial organization, accounting data on profits and costs are not treated as accurately reflecting the underlying economic variables. In our case, we do not have the choice since about half the firms in our sample are small and privately held, and do not disclose even accounting costs and profits. The industry association, NASSCOM, does collect data on software revenues and software professionals employed by the member firms. Managers we interviewed believe that NASSCOM figures are accurate and credible. Accordingly, our research strategy is to develop a formal model from which testable implications of quality certification can be developed using revenue and employment figures, rather than profits.

Our task is simplified by the nature of the Indian software service industry - firms largely provide software development services, where the major input is skilled labor. Land, equipment, physical facilities and data-communication links are other inputs. A questionnaire survey of over a 125 firms, carried out as a part of a related study, confirmed what we heard in our interviews - these factors, although important, are largely a matter of financial resources. Furthermore, we found that banks and financial institutions are willing to lend to software service firms and that virtually none of the software services firms we surveyed, nor those we interviewed, mentioned getting finance as an important problem. ${ }^{12}$

\section{Model}

We assume that the firms produce an output - software services - using only skilled labor. ${ }^{13}$ The price of the output (and hence the cost of producing it) depends on $\alpha$, the fraction of the output that is produced offshore, and on the quality of the output. ${ }^{14}$ The scale of production depends on the number of software professionals the firm employs, which in turn depends upon the ability of firm to attract customers and on other firm characteristics. The variable cost of output depends upon $\alpha$, because the cost of

\footnotetext{
${ }^{12}$ The story is very different for firms developing products, for which getting long term financing is an important problem. We excluded firms that are primarily product developers from our sample.

${ }^{13}$ Alternatively, one might imagine that labor and capital are employed in fixed proportions.

${ }^{14}$ Strictly speaking, the fraction of offshore development affects the unit cost of output. In a competitive industry, price will follow cost quite closely, and our field study confirms this for the Indian software industry.
} 
living for software professionals sent to work on the client site is much higher than for offshore work. Since firms operate in well-integrated labor markets, the salaries are largely determined in the labor market. ${ }^{15}$ In addition, our field studies indicate that the cost of recruiting, hiring and training new professionals is an important part of the firm's costs. Thus, $\Pi$, the firm's profit function can be written as

$$
\Pi=\left[\alpha\left\{p_{x}(\theta)-w_{x}\right\}+\{1-\alpha\}\left\{p_{y}(\theta)-w_{y}\right\}\right] \mathrm{N}(\mathrm{z} ; \theta)-\mathrm{C}\left(\mathrm{N} ; \mathrm{N}_{0}\right)
$$

where $\mathrm{p}_{\mathrm{x}}$ is the price per unit and $\mathrm{w}_{\mathrm{x}}$ is the unit labor cost and $\mathrm{p}_{\mathrm{x}}-\mathrm{w}_{\mathrm{x}} \equiv \pi_{\mathrm{x}}$ represents the net profit from one man-year of offshore software development;. Simiarly, $\pi_{\mathrm{y}} \equiv \mathrm{p}_{\mathrm{x}}-\mathrm{w}_{\mathrm{x}}$ is the net unit profit from onsite software development, where $\mathrm{p}_{\mathrm{y}}$ and $\mathrm{w}_{\mathrm{y}}$ are the unit price and labor cost for onsite software development. We assume that $\pi_{x}>\pi_{y}>$ 0 , i.e., that offshore work is more profitable than onsite work. We also assume, also based on our field research, that $p_{y}>p_{x},\left(\right.$ and $\left.w_{y}>w_{x}\right)$ i.e., that onsite software develop has higher rates than offshore development, but that the labor costs are also correspondingly higher. Both prices are assumed to depend on the quality of service, and therefore, on quality certification, $\theta$. Similarly, the size of the firm, $N$, depends on investments $z$ by the firm in attracting customers, which in turn is assumed to depends on quality certification, $\theta$. The last term of equation (1) captures the cost of recruiting and training new hires, and therefore depends on stock, $\mathrm{N}_{0}$, of experienced software professionals.

The first order condition for the optimal size of the firm is

$$
\frac{\partial \Pi}{\partial \mathrm{z}}=\left\{\left[\alpha\left(\pi_{x}-\pi_{y}\right)+\pi_{y}\right]-\frac{\partial C}{\partial \mathrm{N}}\right\} \frac{\partial \mathrm{N}}{\partial \mathrm{z}}=0
$$

Does quality certification increase profits? Most of the firms we spoke with thought so but there were a couple of exceptions. One of the exceptions was a firm that provided software services to Microsoft, but was also developing software products. The founder and CEO of the firm had well established ties with Microsoft. The firm was not

\footnotetext{
${ }^{15}$ Discussion with software professionals suggests that the salary differentials between different companies are small and salaries depend primarily on skills and years of experience. This is consistent with the observed high labor mobility, with attrition rates of $20 \%$ or more being the industry norm.
} 
certified and not seeking certification. A major reason was that it did not see any benefits. As the CEO put it "Bill (Gates) laughs at CMM", indicating that he too thought such formalized quality certification processes were of limited value for software product development. One reason why the benefits of formal quality processes were thought to be small was that product development requires a great deal of fluidity and does not lend themselves easily to formal documentation of requirements, signoffs on requirements and the like, which such certification often requires.

Moreover, many of the firms that did believe in quality certification could not clearly specify the ways in which quality certification increases profits, other than that it would help them get more business. However, managers at some of the larger firms that had been quality certified for some time were more articulate. In addition to signaling, the ways in which quality certification had or could help their firm included (a) better quality of software (fewer defects, less rework); (b) an enhanced ability to estimate time and resources required for a project, and hence, an enhanced ability to bid for projects; (c) help the firm grow more rapidly by enabling the firm to use less experienced programmers, who are cheaper and more plentiful.

Through a structured methodological approach, we are able to manage the requirements better and estimate the project better. ... With (quality) certification, managers could then be able to get better projects from existing clients. Better would mean larger, more complex, newer technologies, core business applications of the client, product ownership, etc. ... (M)an-hour rate may or may not figure for these improvements. The project may have a higher billing rate. ... The project bid could be higher due to the preventive and appraisal costs of quality. This would ultimately result in lower corrective costs after the software is delivered to the client.

(Quality Assurance Manager, large, certified firm, Bombay.)

Clients are getting extremely quality conscious and the continuation of existing projects depends upon the quality of services delivered. ... Due to quality certification, one can command better projects from existing clients. ...The trend is towards building in bonus and penalty clauses into contracts based on quality \& productivity metrics. The percentage of projects which have such 'service level agreements' is low right now but more and more customers are moving in that direction. In fact in some cases we ourselves are proposing such agreements to customers. ... Through a structured methodological approach, we are able to estimate their requirements better. ... In today's scenario, where we have such a high growth rate, (and a) high recruitment rate, having good processes for software development becomes very important. It would be unimaginable to manage even simple projects without good established processes.

(Head of Quality Assurance Department, large certified firm, Bangalore.) 
In terms of our model, if quality certification increases profits, it can do so in two principal ways. First, certification can increase the quality of the software developed. If so, this should increase the price that the firm can charge per unit of effort. We call this the quality effect. This type of effect should be most visible in time and material contracts. However, even in fixed fee contracts, insofar as the quality of the product is higher, the client should be willing to pay more for a given quantum of effort. When asked about the benefits of quality, most of the Indian firms indicated that they thought that quality was very important. However, they also conceded that only rarely did clients agree to higher rates. A couple of the firms did indicate that they were beginning to earn bonuses for better and more timely work. Clients too, when pressed on this point, confirmed that they often did not give higher rates. ${ }^{16}$ Instead, most agreed that a major benefit of higher quality was the ability to get additional contracts.

In other words, a second possible way in which profits might increase is through increases in the scale of operations. We call the increase in the probability of getting export contracts, by acting as a signal of the firm's ability, the signaling effect. ${ }^{17}$ Note that a firm's scale of operations may also be enhanced by factors which lower the cost of growth (such as by facilitating the induction of new software professionals). However, only a small fraction of the managers we interviewed pointed to this benefit of quality certification. Our sense is that only firms which are committed to an ongoing quality program and have opted to go in for further quality certification such as CMM level 3 or higher have benefited in this fashion.

As noted earlier, we do not observe profits. Instead, we observe revenue and employment. As equation 3 shows, revenue in our simple model is simply the average

\footnotetext{
${ }^{16}$-The effective rate is not a simple contractual matter, particularly under time and material contracts. Better established firms are able to charge for things such as exploratory visits, or visits to negotiate specification changes, that other firms cannot. Similarly, there is considerable scope for discretion in how new and inexperienced members of the software development team are treated. Further, the price per unit of effort depends on how successful the firm is in eliminating rework to fix bugs or estimating project requirements resulting in a smaller fraction of programmers on the "bench" - waiting to be assigned to contracts.

${ }^{17}$ The signaling interpretation also suggests another testable implication that we do not pursue here for lack of data. A substantial fraction of Indian software firms have been ISO certified by mid 1999, and consequently, its value as a signal has eroded considerably (as some managers we interviewed in 1999 noted). Thus, with systematic data over time, one could have tested whether the benefits of certification decline as the percentage of firms that are certified increases. For this study, only firms certified by 1996 are treated as certified.
} 
price per unit of output multiplied by the number of software professionals employed. Thus whereas the quality effect implies a higher price per unit of output (see 4a), the signaling effect implies higher employment, given the price per unit of output (see 4b). Put differently, whereas the quality effect implies higher revenue per employee, the signaling effect implies a larger number of employees for given price.

$$
\begin{aligned}
& \log (\text { Revenue }) \equiv \log (\mathrm{P})+\log (\mathrm{N}) \\
& \Rightarrow \quad \frac{\partial \log (\text { Revenue })}{\partial \theta \text { "quality effect" }}=\frac{\partial \log (\mathrm{P})}{\partial \theta}+\frac{\partial \log (\mathrm{N})}{\partial \theta} \\
& \frac{\partial \log (\mathrm{P})}{\partial \theta}>0 \\
& \frac{\partial \log (\mathrm{N})}{\partial \theta}=\left.\frac{\partial \log (\mathrm{N})}{\partial \theta}\right|_{z}+\frac{\partial \log (\mathrm{N})}{\partial z} \frac{\partial \mathrm{z}}{\partial \theta}>0 \\
& \text { where } \\
& \frac{\partial \mathrm{z}}{\partial \theta}=\frac{\partial^{2} \Pi}{\frac{\partial \theta \partial}{\partial^{2} \Pi}}=\left\{\left[\alpha\left(\pi_{x}-\pi_{y}\right)+\pi_{y}\right]-\frac{\partial C}{\partial \mathrm{N}}\right\} \frac{\partial^{2} \mathrm{~N}}{\partial \mathrm{z} \partial \theta} \quad-\frac{\partial^{2} C}{\partial \mathrm{N} \partial \theta} \frac{\partial \mathrm{N}}{\partial \mathrm{z}} \geq 0
\end{aligned}
$$

A third way that quality certification can increase profits combines elements of both stories. This involves an increase in the fraction of software developed offshore. Recall that offshore development is more profitable than onsite development but that it requires the Indian firm to manage software development to a greater extent, and puts a larger share of the responsibility on the Indian firm. Insofar as quality certification does result in greater offshore development, it implies a lower price per unit of output. We lack acceptable measures of $\alpha$, the extent to which software development is offshore. Self reported measures have tended to be highly exaggerated and the extent of bias varies across firms. Accordingly, we will treat $\alpha$ as an unobservable. This implies that the offshore effect will be confounded to some extent with the quality effect in the empirical analysis. As a practical matter, we believe that this does not matter very much because with one exception, none of the firms we interviewed noted that quality certification helps increase the offshore component. 


\subsection{Empirical specification}

The first order condition given by equation 2 implicitly defines a relationship that determines the size (as measured by employment) of the firm as a function of firm characteristics. In the empirical specification, the log of the number of software professionals depends on firm characteristics, the expected price per unit of output, and quality certification. This gives the first estimating equation. The second equation is simply a variant of equation 3 which specifies the log of revenues as a function of size (log of employment), firm characteristics and quality certification. Thus, equations $5 \mathrm{a}$ and $5 \mathrm{~b}$ represent the estimating equations, where $\mathrm{X}$ and $\mathrm{Y}$ represent firm characteristics, $\mathrm{Q}$ represents ISO certification, and $\mathrm{N}$ and $\mathrm{R}$ represent software employment and revenues. In the revenue equation $5 \mathrm{~b}, \mathrm{P}$ represents the average price (see equation 2 also).

$$
\begin{aligned}
& \log (\mathrm{N})=\beta_{n} \mathrm{X}+\gamma_{n} \mathrm{Q}+\lambda_{n} \hat{\mathrm{P}}+\varepsilon_{n} \\
& \log (\mathrm{R})=\beta_{r} \mathrm{Y}+\gamma_{r} \mathrm{Q}+\lambda_{r} \mathrm{~N}+\varepsilon_{r}
\end{aligned}
$$

Note that the signs of $\gamma_{n}$ and $\gamma_{\mathrm{r}}$ correspond to the impact of quality certification on the ability of the firm to grow and on the price per unit of output. In turn, these correspond, albeit only imperfectly, to the signaling and quality effects discussed earlier. ${ }^{18}$ We estimate these equations, first by assuming that quality certification is exogenous, and then by treating it as endogenous and instrumenting for it. It is plausible that actual quality of service may depend not only on whether the firm is certified but also for how long it has been certified. Accordingly, we estimate two specifications, one where ISO certification is dichotomous variable and another where we use the number of years for which the firm has been ISO certified, ISOAGE. Although it seems reasonable to posit that on average the elasticity of revenue with respect to size is one, our field studies point to the possibility that larger firms may be able to win and execute more complex (and higher paying) projects. In turn, this would imply an elasticity greater than one. Thus we allow the coefficient on size in the revenue equation to differ from unity.

\footnotetext{
${ }^{18}$ In going from the impact on unit price to the quality effect of ISO certification, we are neglecting the offshore effect. This point is also discussed further below.
} 


\section{Data: Sources and Limitations:}

Our data come from two primary sources. The data on revenue, employment, age, public status and quality certification are from the NASSCOM directory of Indian software companies. NASSCOM member companies generate $95 \%$ of the industry revenues, and the NASSCOM coverage of its members is fairly systematic. All the firms in our sample develop software, mainly for other firms. Nearly $80 \%$ of the firms in our sample have software exports accounting for more than $75 \%$ of their revenues. We excluded firms that are purely domestic focused or those that provide web-hosting services, or that are value added resellers for large packaged software companies in the US. In addition, we removed very small firms (fewer than 10 employees) and firms that were younger than 2 years. ${ }^{19}$ This procedure left us with 95 firms on which we had reasonably complete data. These firms accounted for over $60 \%$ of the total industry revenue in 1997.

We used revenue and employment data for 1996-97. Wherever possible, the revenue and employment figures were also obtained for 1992-93 and interim years as well. We converted all rupee revenues for a particular year into dollars by using the average exchange rate for that year. We use the average revenue per employee for 199495, 1995-96, 1996-97 a proxy for the "expected price per unit of output" in the employment equation. The size of the firm is measured by the log of employment. ${ }^{20}$ In some cases, where NASSCOM data on employment or revenues was missing, we used data published in Dataquest, an Indian trade journal. We have information on whether a firm is quality certified and the year in which certification was first obtained. For this study, only firms that obtained ISO certification in or before 1996 are considered to be quality certified.

In addition, using NASSCOM, our questionnaire survey and other sources, we created a series of control variables to control for whether the firm is privately or publicly

\footnotetext{
${ }^{19}$ The direct cost of ISO certification is approximately Rs. 40,000 (\$1000) per day and would take 4 days for a company with 200 employees (Gopal, 1996). A firm that size would typically earn revenue of \$5-6 million per year. We lack measures for the indirect opportunity cost of preparing for certification and implementing the processes and documentation required to maintain certification status. Although a firm of any size can get certified, industry consultants we interviewed consider 10 employees to be a minimum sensible threshold. NASSCOM has proposed that all firms above a size of 10 employees should get certified by the year 2000 .

${ }^{20}$ For firms with non-software businesses as well, we include only employment in the software business.
} 
owned and whether it is a subsidiary or division of a foreign company, providing software developing exclusively for the parent. The latter includes well-known cases such as the software operations of Motorola, Texas Instruments, Cadence, Hughes Networks and Baan Infosystems. The variables used are defined in Table 2a.

Table $2 \mathrm{~b}$ gives the descriptive statistics for the sample. The average revenue per employee for the sample is about $\$ 24,000$. This fits the industry perception where onsite work is billed at about $\$ 90,000$ per employee per year, compared to about $\$ 30,000$ for offshore work and about $\$ 10,000-\$ 15,000$ for domestic work. The distributions of both size and revenues are skewed as shown in figures $2 \mathrm{a}$ and $2 \mathrm{~b}$. For instance, the average size is 482 employees but the median size is only 200 employees. Similarly, while average revenue is $\$ 11.72$ million, the median revenue is only $\$ 3.1$ million. We verified that these distributions are approximately log normal. About half of the firms are quality certified, and slightly less than half are privately held.

The key identifying instruments for the size equation are lagged size, measured as the log of the number of software professionals employed by the firm in 1992 (EMP92), and whether the firm focuses on non OECD markets, such as the Middle East or Africa (LDC_EXP). Since the cost of growth depends on the stock of experienced professionals employed by the firm, lagged size is a natural instrument. In addition, the growth in the US and European markets for software development has been much greater than from developing country markets. To identify the revenue equation we use a variable that measures whether the firm is part of a group of firms that have overlapping ownership and management, often associated with a single family (GROUP). Another instrument for revenue is whether the firm also develops and distributes software products (PRODCT).

When we treat ISO certification itself as endogenous we use as instruments a dummy for whether the firm is publicly traded (PUBSTAT) and whether the firm came into existence after 1992 (YOUNG). Publicly traded firms might better resources and may also have greater incentives (such as signaling to capital markets) to get ISO certification. In addition, ISO standards themselves first come to prominence around 1991 or 1992 . Thus, firms entering the industry after 1992 are likely to acquire quality 
certification sooner after being founded than firms established earlier. Hence, controlling for age, YOUNG is a candidate instrument, especially for ISOAGE.

Other characteristics of the firm used as explanatory variables in both regressions, are whether the firm is operated as a cost center of an overseas firm (CAPTIVE), whether it has a substantial fraction (30\% or more) of its staff devoted to research and product development (HI_R\&D), the age of the firm (LogAGE) and the percentage of revenues due to exports (EXPORT). ${ }^{21}$ We also experimented with other controls such as location but with little change to the qualitative results. In view of the relatively small sample size, we settled for a more parsimonious specification.

\section{Analysis and Results}

We begin with the ordinary least squares estimates of the estimating equations $5 \mathrm{a}$ and 5b. Panel A of Table 3 displays the results using ISOAGE and panel B displays the results where ISO certification is as a dichotomous variable (ISO). The results are similar across the two specifications. ISO certification has a positive and significant impact on employment and the impact on revenue is positive, albeit not statistically significant. The point estimate of the elasticity of revenue with respect to employment is slightly greater unity, although not significantly different from unity. As well, we see that firms with substantial R\&D (HI_R\&D) tend to have higher revenues (given size) but are somewhat smaller on average. In the employment equation, the five year lagged employment is positive but the elasticity is small and imprecisely estimated. Although initially surprising to us, this is consistent with the fairly rapid growth in the industry, implying that lagged size is not a very powerful determinant of current size. Since most of the growth has come from exports to the US and other rich countries, firms that focused on the domestic market or on markets of other developing countries (LDC_EXP) are, all else constant, much smaller. Finally, membership of a business group (GROUP) is associated with higher revenues, given employment. This suggests that software firms belonging to business groups have an advantage in negotiating with clients and can leverage the reputation of the group to get better rates.

\footnotetext{
${ }^{21}$ In order to obtain some of the control variables such as PRODCT, HI_R\&D, and LDC_EXP, we classified firms by reading through the firm's profile in the NASSCOM directory, supplemented by information available from the company's website and from our interviews and questionnaire survey.
} 
Table 4 shows the results of OLS estimates of how ISO and ISOAGE are related to the various exogenous variables used in the analysis. Although there are some differences in the statistical significance of coefficients across the equations, the patterns, are broadly similar - older, larger firms, publicly traded firms and firms with very strong export orientation are more likely to be quality certified and for longer. As with the results reported above in Table 3, these results are interesting but cannot be given a causal interpretation.

We begin by endogenizing revenue and employment, but still keeping ISO certification exogenous. Table 5 reports results of GMM estimates of equations $5 \mathrm{a}$ and 5 b estimated as a system. We estimate two specifications, using ISOAGE and ISO respectively. As noted earlier, we use membership in a business group (GROUP) and involvement in developing and distributing software products (PRODCT) to identify the revenue equation. The employment equation is identified by lagged size, $\log ($ EMP92), and by LDC_EXP. As in the OLS estimates, the estimates are similar between the ISO and the ISOAGE specification. Focusing on the ISOAGE specification, we see that the elasticity of revenue with respect to ISOAGE is about 0.29 , a little less than the OLS estimate of 0.34 . The GMM estimates are qualitatively similar to those from the OLS for the employment equation, although the GMM estimate of HI_R\&D somewhat larger in magnitude compared to the corresponding OLS estimate. The similarity between the OLS and GMM estimates holds for the revenue equation as well, although the GMM estimate of ISOAGE is almost zero, compared with 0.08 in the OLS (although not statistically significant either). Also, the elasticity of revenue with respect to size is now 1.34 , although still not statistically different from unity. Finally, the coefficient on expected price implies that a $\$ 1000$ increase in the expected price per unit of effort (compared to a median value of nearly $\$ 21,000$ ) increases employment by about $4-5 \%$. Since median size is about 200 , this amounts an increase of $8-10$, a small but statistically significant effect.

Table 6 presents the results where we instrument for ISO certification. As noted earlier, we use PUBSTAT and YOUNG as instruments. ${ }^{22}$ Focusing on the estimates in panel A, we find that the qualitative results are similar to Table 5 although the magnitude

\footnotetext{
${ }^{22}$ We tested for and could not reject the overidentifying restrictions implied by our specification.
} 
of the point estimates differ somewhat. In the size equation, the most noticeable change is that elasticity of size with respect to ISOAGE almost doubles to 0.59 . In the revenue equation, the pattern of results is generally the same although once again the magnitude , of the point estimates does vary between Table 5 and Table 6 . The other major difference is in the estimate of elasticity of revenue with respect to size, which increases from 1.34 to 1.55 , albeit still not significantly different from unity. Taken at face value, this suggests that larger firms may be able to earn a higher price per unit of effort, possibly because they are able to undertake larger and more complex projects.

Turning to other coefficients, we find that firms with a focus on research and development tend be smaller, but have higher revenues conditional on size. Somewhat to our surprise, conditional on other controls, the age of the firm does not matter much, either for employment or size. This might be because many of the other variables are strongly correlated with age, especially lagged size and YOUNG. The small coefficient on age may also be linked to the rather large elasticity of revenue with respect to size. Also surprising to us was the consistently negative coefficient of EXPORT in the revenue equation. It is possible that this variable is picking up unobserved variations in the percentage of offshore development, because it is plausible that firms with a larger fraction of offshore development also tend to export more.

The results are similar when one uses ISO instead of ISOAGE (panel B). In the employment equation, instrumenting for ISO tends to reduce the absolute magnitudes of most of the point estimates, except for the coefficient of ISO itself, which more than doubles in value. The revenue equation estimates are remarkably stable even after instrumenting for ISO. In general, the estimates using ISOAGE are more robust to the inclusion or exclusion of various controls.

Considering the results in tables 5 and 6, along with the OLS estimates, we conclude that the impact of ISO certification on size is large and significant, and appears to be larger, the longer the firm has been ISO certified. By contrast, the impact of ISO certification on price per unit (revenue conditional on employment) is much smaller, and appears somewhat sensitive to the specification.

To understand the quantitative significance of the results, it is helpful to consider the impact of being quality certified for one year. Note that quality certification will 
affect revenue in a number of ways - by increasing employment and by increasing the average rate indirectly through the change in employment. As well, there will be second round impacts because an increase in the average rate will further affect employment and so on. Taken together, the estimates in Table 6, panel A imply that the combined direct and indirect impact of one additional year of quality certification is to increase expected revenue by about $110 \% .{ }^{23}$ In other words, for the median sized firm with revenues of \$3.1 M and 200 software professionals, one year of quality certification means an increase of nearly $\$ 3.4 \mathrm{M}$ in revenue and 117 in employment. If instead one uses the estimates in Table 5 (treat ISOAGE as exogenous), then the total effect of one year of ISO certification would be to increase revenue by about $\$ 1.4 \mathrm{M}$ and employment by 62 for the median firm. The direct impact on rates is almost zero. However, the indirect impact, through the increase in size is substantial, and varies between $\$ 3,000$ and $\$ 1,400$, or $15 \%$ and $7 \%$ respectively of the median rate of $\$ 21,000$.

In general, the estimated impacts are larger than what we expected, especially those obtained from treating ISO certification as endogenous. But even the lowest estimates imply a fairly substantial impact of ISO certification. Consistent with the field studies, the bulk of the impact is through increasing the size of the firm, which directly increases revenue (and profits), and by increasing the price per unit of effort, has a further increases revenues and profits.

\section{Discussion}

We find that ISO certification enhances the ability of firms to grow, but with only a modest impact at best on the rates it can get. Our results are consistent with the two main themes that emerge from the field study: ISO certification is an important means of signaling to potential customers (and hence, of enabling the firm to grow more rapidly), and that ISO certification does help in enabling a firm with the ability to provide more sophisticated and higher value added services to get such contracts, and hence earn higher price per unit of effort. The results with respect to growth are much stronger and consistent across different types of specification than the impact on rates. Virtually all the

\footnotetext{
${ }^{23}$ The inherent non-linearity of the specification of the estimating equation implies that these estimated impacts cannot be exactly calculated.
} 
managers we spoke with noted that quality certification was a way for them to market their firm to overseas clients. A senior consultant who audits firms for quality certification explicitly said that the one of the major benefit of quality certification was to enable the certified firm to get a "foot in the door".

The signaling story is also consistent with the results in on the contracts entered into by Indian software firms reported by Bannerjee and Duflo (1998). They find that younger firms are more likely to try to signal their ability by accepting fixed price contracts and being responsible for a larger fraction of the cost over-runs in time and material contracts. They too find that the average impact of quality certification on the fraction of cost overrun that the Indian software firm pays is small. Interestingly enough, they also find that young firms that are ISO9001 certified appear to be closer in this respect to older firm, and that the impact of quality certification on the contractual variables is much greater for younger firms than for older firms. ${ }^{24}$

Although we interpret our findings in terms of signaling and quality of service respectively, these are not the only possible interpretation. For instance, the small direct impact on rates may reflect an offsetting increase in $\alpha$, the offshore percentage. Such an increase, while increasing profit, would decrease the average rate. Similarly, it is conceivable that superior quality of service be reflected not in the price but through the client providing repeat business and larger and more sophisticated contracts. The impact on size may not reflect only signaling either. Quality certification can enhance growth by reducing the cost of growth. Managers at a large Delhi based firm noted that defining and documenting their software development methodology had helped when new and less experienced members were added to the business division, and when experienced team members quit. Although not as frequently mentioned as signaling, this point was also raised by managers from firms that had been quality certified for some time.

The relatively greater importance of ISO certification as a signaling device is certainly consistent with its use in other industries such as electronics, and with its various deficiencies as a program for sustained quality improvement (Cole, 1999). But ISO certification does require that the software development processes be defined and documented. Surely this alone should help reduce errors and bugs in the software

\footnotetext{
${ }^{24}$ They do not provide results by firm size.
} 
developed. Better signoff and acceptance procedures should reduce the extent to which requirements change, more systematic testing procedures should detect bugs early, and better documentation should make it easier to fix bugs once detected. In other words, even if not the intent, obtaining certification should improve quality. Although correct in principle, our field research suggests that the direct economic impact of any quality increase will be small, at least in the short run. In terms of the waterfall model of software development, most of the export projects by Indian firms involve low level design, coding and some extent of testing. Requirements analysis or high level design are typically not entrusted to them. A design flaw is much costlier to rectify and very difficult to detect until much later in the development cycle. Bugs introduced at later stages such as in coding are relatively easy to detect and fix, compared with those introduced at an early stage. Indeed, most clients carry out independent acceptance testing where such bugs can be detected.

Our field research reveals that the bulk of the software development projects outsourced to Indian firms are relatively small, not very demanding in terms of technical sophistication. Our interviews with US firms confirm that they do not outsource projects that are either on the technological frontier or are mission critical to their business. The upshot of all this is as that lower quality - more bugs in the code, and more ad hoc development practices - is not as costly as it might otherwise be, and neither are the rewards for higher quality as high.

In other words, the relatively small impact implied on rates in most specifications of the revenue equation is consistent with the picture of a rapidly growing industry, but with many small firms, each quite small in relation to its clients in size and experience. In the initial growth period, clients outsource fairly simple projects where the value to the client of systematic and well-defined software development processes, of quality certification itself, is low. However, many, if not most, Indian firms are capable of doing more complex and sophisticated projects. In such situations, most of them would prefer a strategy where short term profits are sacrificed for more rapid growth, and getting quality certified and providing higher quality, not for higher rates but for more business, is a viable way to grow. 


\section{Conclusions}

Proponents of quality certification typically believe that the adoption of quality measurement and improvement processes improves the quality of the output, and thereby provides economic benefits to the firm. Our analysis suggests that the benefits of ISO certification arise largely because such certification allows firms Indian firms to signal to potential customers. Although quality certification can also increase the rates per unit of effort, these effects are modest, at least initially. Firms that have been certified for some time may able to command higher rates. However, both the econometric results and the interviews suggest that relatively few firms are in this happy position. For these firms, which are almost all committed to an ongoing software quality program, ISO certification does act as the first step. For them, the field research indicates that ISO certification does appear to have benefits, in terms of helping them manage growth and deal with the high rates of employee turnover that are endemic to the industry.

Our findings are consistent with the current state of evolution of the industry. Many of the firms are young and immature but growing rapidly. Despite this, most of their potential clients in the US and Europe are not confident of the ability of Indian firms. As a consequence, the Indian software firms are getting ISO certified in order to signal that their software development processes are defined and documented, not so much in order to get higher rates per unit of effort, but to get larger contracts, and eventually, to get better and more profitable contracts as well. It also follows that a larger fraction of firms get certified, ISO certification loses its potency as a signal to potential customers. In other words, our results may not generalize directly to other industries or to other countries. However, there are some insights that apply broadly.

Hitherto, quality programs and quality certification have been conceived of as essentially firm or business unit level phenomena. The implicit assumption has been that quality programs directly affect the internal processes of the firm and only through those do they affect economic performance. However, under some conditions, quality certification can affect economic performance in other ways as well, for instance as a signal to potential customers. The more important conclusion is that in order to understand quality programs and their impact, one must also understand the competitive environment in which the firm operates. 


\section{Appendix: Field Research Methodology}

Our site visits were done in three trips. On the first trip in December 1997, we visited seventeen software developers in Bangalore, Bombay and Hyderabad. "The visits, lasted from three hours to half a day per firm. The interviews were typically with the CEO or member of the top management of the firm. They were loosely structured around a set of broad set of questions relating to how the firm was started and how its choice of location was decided, the firm's evolution over time, including any significant changes in strategy and structure. The questions also included questions on the type of projects the firm had undertaken both domestically and overseas, how it got business from overseas clients and the major challenges the firm faced, and its strategy for dealing with those changes. In this context many firms discussed initiatives they had undertaken for improving the quality of their processes. The field interviews were followed up by telephone interviews of 30 minutes to an hour with twelve US based client of the firm visited. ${ }^{25}$ These interviews took place in the first part of 1998. As a part of these telephone interviews we specifically asked about the importance of quality certification in how software suppliers are selected and in the billing and other contractual arrangements.

In a second trip to India in June 1998, we spent considerable time at two large firms (including one that does not readily allow access to outsiders), that are now assessed at CMM level 4. On this trip, one of us who has worked in the software services industry in India also had a chance to compare software development practices between firms with and without quality certification. On the second trip we also interviewed a firm that provides guidelines to software firms seeking a quality certificate. These interviews were sometimes followed up by sustained email exchanges. Finally, we have had informal discussion with the CEO a US firm with a substantial India based software development operation. This firm competes with Indian software firms in providing software development services. We also spoke with the CEO of an old, privately held Indian software service firm. These informal conversations gave us valuable background material on the nature of competition, pricing and contractual arrangements in the industry.

The third trip was shorter but included a day long visit to a large Delhi based software firm, with interviews with managers at different levels, including the chief operating officer. The software consulting division of this firm is headed by an industry veteran who was also responsible for quality initiatives at one of the firms that pioneered ISO certification and SEI certification in the industry.

\footnotetext{
${ }^{25}$ The interviews were arranged by the Indian firm, and thus are not a random sample of the clients. Nonetheless, our interviewees were remarkably candid in their assessment of the strengths and weaknesses of their Indian suppliers.
} 
Albrecht, A., J., and Gaffney, J.,E., 1983, IEEE Transactions on Software Engineering, SE-9, 6, 639-648.

Arora, A., Arunachalam, V.S., Asundi, J. and Fernandes, R., 1998, The Indian Software Industry, working paper, Heinz School.

Boehm, B.W., 1981, Software Engineering Economics, Prentice-Hall, Englewood Cliffs; NJ.

Boehm, B.W., 1987, Improving Software Productivity, Computer, pp. 43-57, September

Cole, Robert, 1999, Managing Quality Fads, Oxford University Press, New York.

Dion, Raymond, 1993, Process Improvement and the Corporate Balance Sheet, IEEE Software, pp. 28-35, July.

Gopal, Anandasivam, 1996, An Empirical Analysis of Offshore Software Development: A First Look At Some Explanatory Factors", forthcoming in Communications of the ACM.

Halstead, M., 1977, Elements of Software Science, Elsevier North-Holland, New York.

Heeks, R., 1996, India's Software Industry: State policy, liberalization and industrial development, Sage Publications.

Herbsleb, J., Zubrow, D., Goldenson, D., Hayes, W. and Paulk, M., Software Quality and the Capability Maturity Model, 1997, Communications of the ACM, Vol. 40, No. 6., July.

Humphrey, W. S., Snyder, T. R. and Willis, R. R., 1991, Software Process Improvement at Hughes Aircraft, IEEE Software, pp 11-23, July.

Infac, 1998, Indian Software Market Status, Bombay, January, pp. 15

Jones, Capers, 1998, Sizing Up Software, Scientific American, pp. 104-109, December.

Kehoe, R. and Jarvis, A., 1996, ISO 9000-3: A Tool for Software Product and Process Improvement, Springer-Verlag, New York.

McCabe, T.J., 1976, A Complexity Measure, IEEE Transactions, SE-2,

Meadows, C. J., 1996, Globework: Creating technology with international teams, Ph.D. Thesis, Graduate School of Business Administration, Harvard University.

National Association of Software and Service Companies (NASSCOM), 1994-95, 199697 1997-98, A Directory of Indian soft ware service companies

P. Jalote, 1991, An Integrated Approach to Software Engineering, Springer-Verlag, New York.

Paulk, M. C., Curtis, B., Chrissis, M. B. and Weber, C. V., 1993, Capability Maturity Model for Software, Version 1.1 (CMU/SEI-93-TR-24, ADA 263403), Pittsburgh, PA, Software Engineering Institute, Carnegie Mellon University.

Paulk, Mark C., 1994, A comparison of ISO 9001 and the Capability Maturity Model for Software, Technical Report from SEI, CMU/SEI-94-TR-12, July.

Radice, Ronald, 1995, ISO9001 Interpreted for Software Organizations, Paradoxicon Publishing.

Slaughter, S. A., Harter, D. E. and Krishnan, M. S., Evaluating the Cost of Software Quality, Communications of the ACM, Vol. 41, No. 8., August 1998

Software Engineering Standards, IEEE Press, 1987 
</ref_section> 


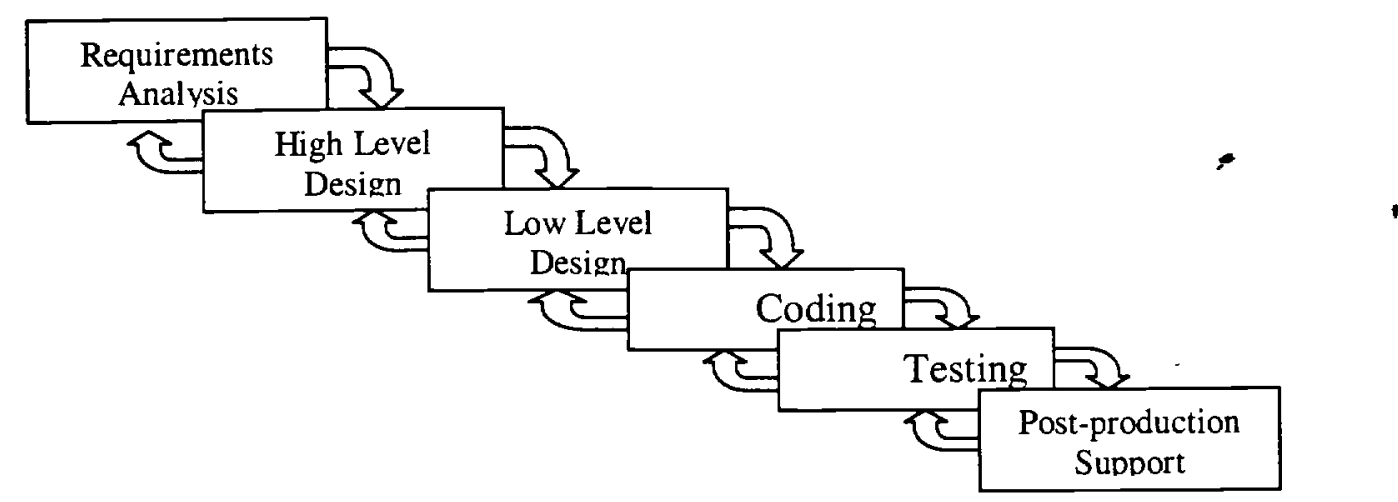

Fig 1: The waterfall model of software development 


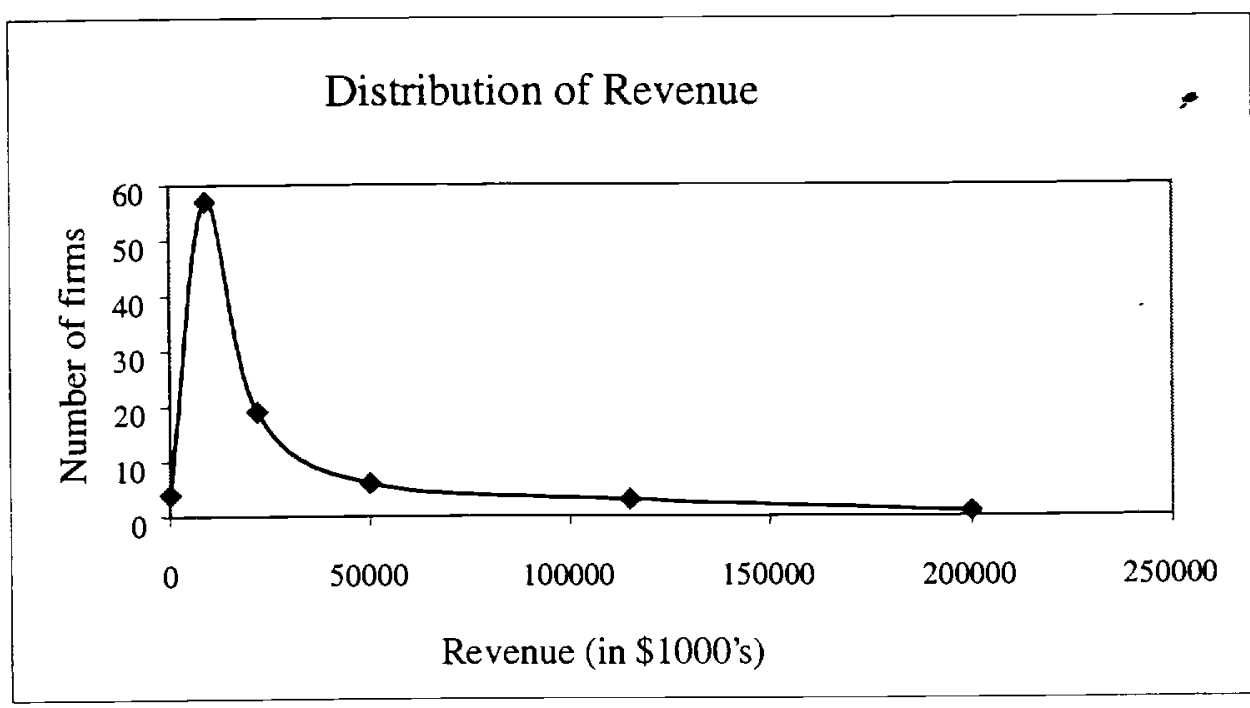

Fig 2a: distribution of sample firms

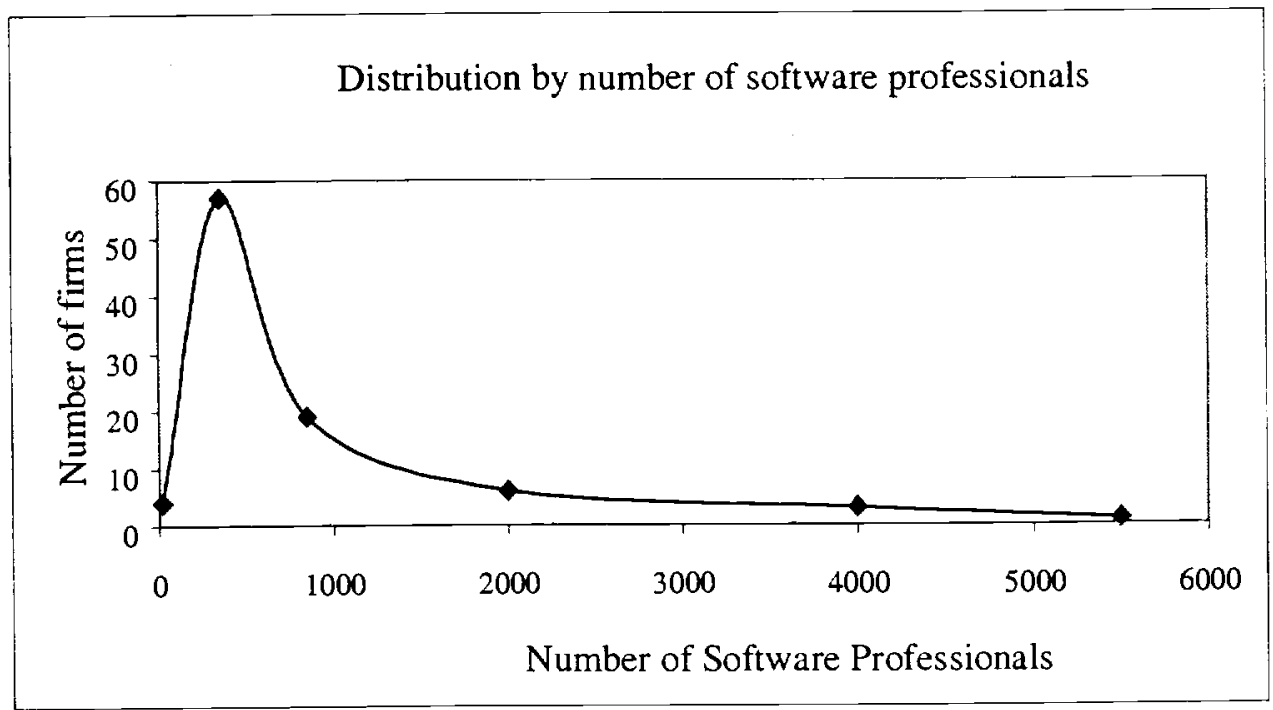

Fig 2b: Size distribution of sample firms 
Table 1: Growth of quality certification among Indian software firms, 1994-98

\begin{tabular}{l|c|c}
\hline Year & Firms quality certified & Plans to acquire with 2 years \\
\hline $1994-95$ & 16 & 137 \\
$1995-96$ & 30 & 142 \\
$1996-97$ & 58 & 119 \\
$1997-98$ & 89 & 136 \\
\hline
\end{tabular}

Source: NASSCOM, 1998

Table 2a: Description of variables used

\begin{tabular}{|c|c|}
\hline Variable & Description \\
\hline LOG(Revenue) & Natural log of software revenue in 1997 \\
\hline LOG(Employ) & Natural log of software professionals in 1997 \\
\hline AV_RATE & $\begin{array}{l}\text { This is the average revenue per employee earned by the firm over 1995, } \\
1996 \text { and 1997, (in '000s of \$) }\end{array}$ \\
\hline AGE & Age of the company (or the software division as appropriate), in years \\
\hline LOG(EMP92) & $\begin{array}{l}\text { Natural log of number of software professional employed by the firm in } \\
1992\end{array}$ \\
\hline $\log (\mathrm{AGE})$ & Natural logarithm of the AGE \\
\hline $\mathrm{ISO}=1$ & Firm is ISO certified \\
\hline ISO_AGE & Age since the firm first acquired ISO certification. \\
\hline EXPORT & Software export as percentage of the firm's software revenues \\
\hline GROUP $=1$ & $\begin{array}{l}\text { Firm is part of a group of firms that have overlapping ownership and } \\
\text { management, often associated with a single family }\end{array}$ \\
\hline HI_R\&D=1 & R\&D personnel are $30 \%$ or more of the firm's employment \\
\hline LDC_EXP=1 & $\begin{array}{l}\text { Firm focusing on non-OECD markets, such as the Middle East, Africa } \\
\text { or India. }\end{array}$ \\
\hline PUBSTAT $=1$ & Firm is publicly traded \\
\hline CAPTIVE $=1$ & Firm is operated as a cost center of an overseas firm \\
\hline PRODCT $=1$ & Firm also develops and distributes software products \\
\hline YOUNG=1 & Firm came into existence after 1992 \\
\hline
\end{tabular}


Table 2b: Sample Descriptive Statistics ( $\mathrm{N}=95$ )

\begin{tabular}{l|rrrr}
\hline Variable & Mean & Std Dev & Minimum & Maximum \\
\hline REVENUE in 1997(\$'000) & 11723.76 & 25462.34 & 14.12 & 203652.54 \\
EMPLOYEES in 1997 & 481.98 & 1045.62 & 15 & 9000 \\
LOG(Revenue) & 8.07 & 1.745 & 2.65 & 12.22 \\
LOG(EMP) & 5.22 & 1.35 & 2.70 & 9.10 \\
AV_RATE (\$'000 per worker) & 23.36 & 15.73 & 0.81 & 83.76 \\
AGE (years) & 10.64 & 5.30 & 2.00 & 31.00 \\
Log(AGE) & 2.25 & 0.48 & 0.69 & 3.43 \\
ISO & 0.49 & 0.50 & 0 & 1 \\
ISO_AGE & 3.17 & 1.11 & 2 & 6 \\
LOG(EMP92) & 3.08 & 2.5 & 0 & 8.77 \\
EXPORT & 0.69 & 0.35 & 0 & 1 \\
GROUP & 0.19 & 0.39 & 0 & 1 \\
HI_R\&D & 0.12 & 0.32 & 0 & 1 \\
LDC_EXP & 0.28 & 0.45 & 0 & 1 \\
PUBSTAT & 0.46 & 0.50 & 0 & 1 \\
CAPTIVE & 0.07 & 0.26 & 0 & 1 \\
PRODCT & 0.14 & 0.35 & 0 & 1 \\
YOUNG & 0.17 & 0.38 & 0 & 1 \\
& & & & \\
\hline
\end{tabular}

1. Sample of 47 quality certified firms only. Firms certified before 1996 only are counted as ISO certified. 
Table 3a: OLS Estimates of Estimating Equations

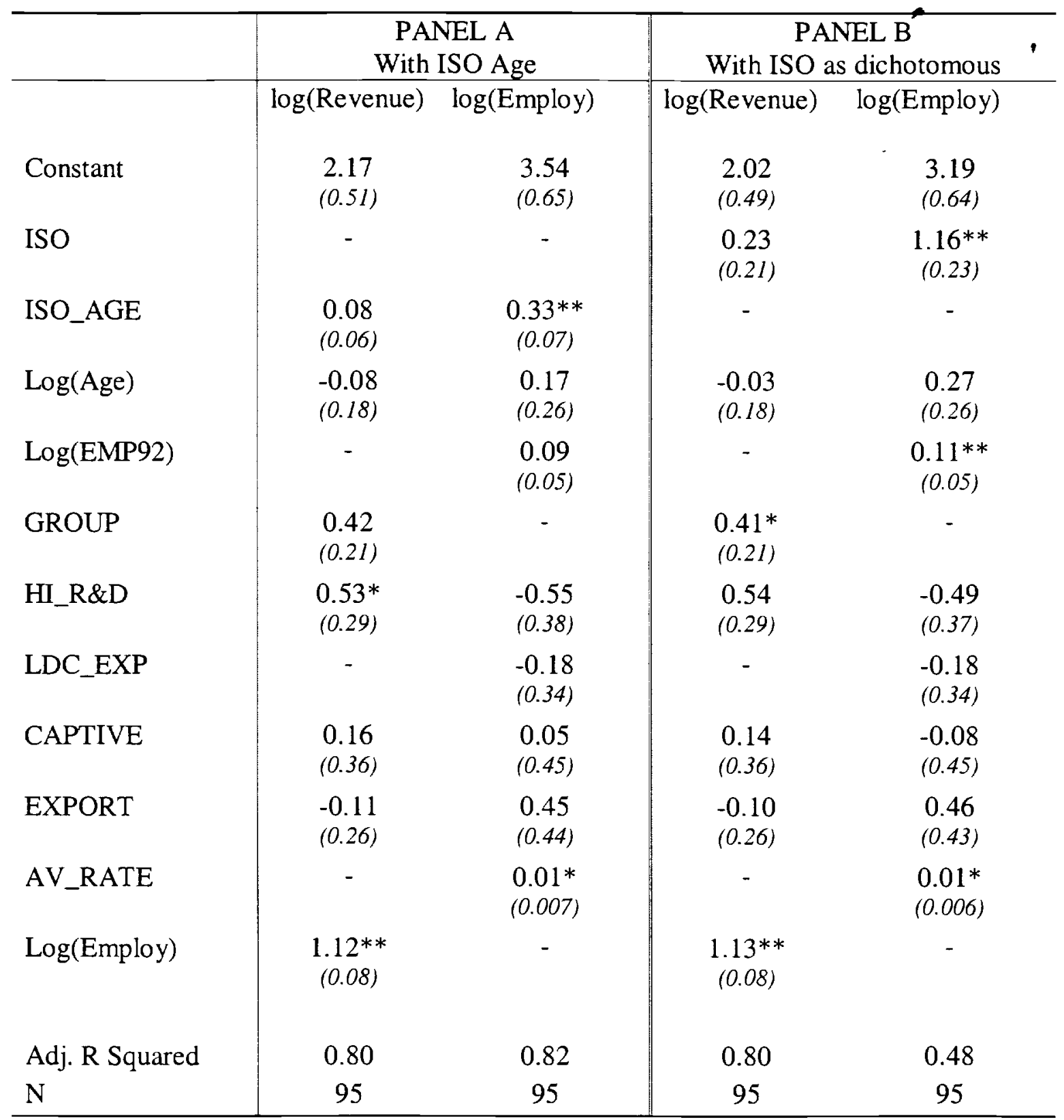


Table 3b: Reduced Form OLS Estimates

\begin{tabular}{|c|c|c|}
\hline $\begin{array}{l}\text { Dependent } \\
\text { Variable }\end{array}$ & $\log ($ Revenue $)$ & $\log ($ Employment $)$ \\
\hline Constant & $\begin{array}{l}5.88 \\
(1.17)\end{array}$ & $\begin{array}{c}3.27 \\
(0.88)\end{array}$ \\
\hline Log(EMP92) & $\begin{array}{c}0.24^{* *} \\
(0.08)\end{array}$ & $\begin{array}{c}0.20 * * \\
(0.06)\end{array}$ \\
\hline Log(Age) & $\begin{array}{c}0.41 \\
(0.44)\end{array}$ & $\begin{array}{c}0.39 \\
(0.33)\end{array}$ \\
\hline GROUP & $\begin{array}{l}0.68 \\
(0.41)\end{array}$ & $\begin{array}{c}0.30 \\
(0.31)\end{array}$ \\
\hline HI_R\&D & $\begin{array}{l}-0.23 \\
(0.55)\end{array}$ & $\begin{array}{c}-0.71 * \\
(0.41)\end{array}$ \\
\hline LDC_EXP & $\begin{array}{l}-0.70 \\
(0.51)\end{array}$ & $\begin{array}{r}-0.35 \\
(0.38)\end{array}$ \\
\hline CAPTIVE & $\begin{array}{c}0.61 \\
(0.69)\end{array}$ & $\begin{array}{c}0.40 \\
(0.52)\end{array}$ \\
\hline EXPORT & $\begin{array}{c}0.44 \\
(0.65)\end{array}$ & $\begin{array}{c}0.64 \\
(0.49)\end{array}$ \\
\hline PRODCT & $\begin{array}{l}-0.55 \\
(0.46)\end{array}$ & $\begin{array}{c}-0.65^{*} \\
(0.34)\end{array}$ \\
\hline PUBSTAT & $\begin{array}{c}0.50 \\
(0.33)\end{array}$ & $\begin{array}{c}0.30 \\
(0.25)\end{array}$ \\
\hline YOUNG & $\begin{array}{c}0.63 \\
(0.56)\end{array}$ & $\begin{array}{c}0.46 \\
(0.42)\end{array}$ \\
\hline Adj. R Squared & 0.29 & 0.34 \\
\hline $\mathrm{N}$ & 95 & 95 \\
\hline
\end{tabular}


Table 4: OLS Estimates of ISO and ISO_AGE

\begin{tabular}{l|c|c}
\hline & ISO_AGE & ISO \\
\hline Constant & -0.90 & 0.13 \\
Log(AGE) & $(1.15)$ & $(0.36)$ \\
Log(EMP92) & 0.39 & 0.00 \\
& $(0.43)$ & $(0.13)$ \\
GROUP & $0.28^{* *}$ & $0.06^{* *}$ \\
& $(0.08)$ & $(0.02)$ \\
HI_R\&D & -0.29 & -0.02 \\
& $(0.41)$ & $(0.13)$ \\
LDC_EXP & -0.56 & -0.23 \\
CAPTIVE & $(0.54)$ & $(0.17)$ \\
& -0.29 & -0.10 \\
PRODCT & $(0.50)$ & $(0.15)$ \\
& 0.31 & 0.20 \\
PUBSTAT & $(0.68)$ & $(0.21)$ \\
& -1.08 & $-0.26 *$ \\
EXPORT & $(0.45)$ & $(0.14)$ \\
YOUNG & $0.68^{* *}$ & 0.14 \\
& $(0.33)$ & $(0.10)$ \\
Adj. R Squared & 0.98 & 0.25 \\
N & $(0.64)$ & $(0.20)$ \\
\hline
\end{tabular}


Table 5: GMM Estimates, Treating ISO as Exogenous

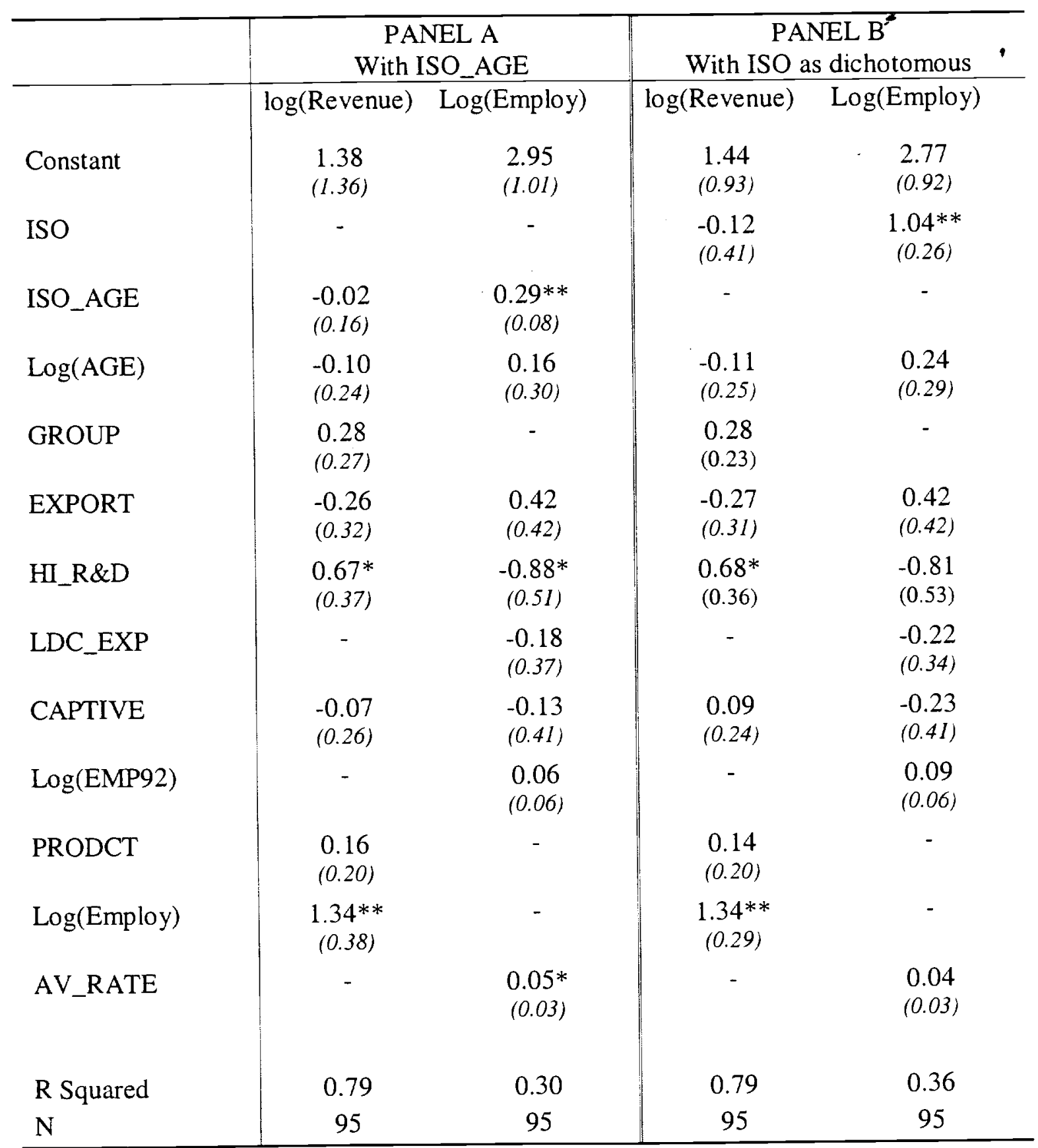


Table 6: GMM Estimates, Treating ISO as Endogenous

\begin{tabular}{|c|c|c|c|c|}
\hline & \multicolumn{2}{|c|}{$\begin{array}{c}\text { PANEL A } \\
\text { With ISO_AGE }\end{array}$} & \multirow{2}{*}{\multicolumn{2}{|c|}{$\begin{array}{c}\text { PANEL B } \\
\text { With ISO as dichotomous } \\
\log (\text { Revenue }) \quad \log (\text { Employ })\end{array}$}} \\
\hline & $\log ($ Revenue $)$ & Log(Employ) & & \\
\hline Constant & $\begin{array}{l}0.49 \\
(2.55)\end{array}$ & $\begin{array}{l}3.10 \\
(1.2)\end{array}$ & $\begin{array}{c}1.5 \\
(2.44)\end{array}$ & $\begin{array}{l}2.53 \\
(1.27)\end{array}$ \\
\hline ISO & - & - & $\begin{array}{l}0.08 \\
(2.39)\end{array}$ & $\begin{array}{c}2.55^{* *} \\
(1.11)\end{array}$ \\
\hline ISO_AGE & $\begin{array}{l}-0.17 \\
(0.43)\end{array}$ & $\begin{array}{c}0.59 * * \\
(0.24)\end{array}$ & - & - \\
\hline Log(Age) & $\begin{array}{l}-0.13 \\
(0.23)\end{array}$ & $\begin{array}{l}0.07 \\
(0.33)\end{array}$ & $\begin{array}{l}-0.11 \\
(0.31)\end{array}$ & $\begin{array}{c}0.28 \\
(0.33)\end{array}$ \\
\hline Log(EMP92) & - & $\begin{array}{l}-0.02 \\
(0.08)\end{array}$ & - & $\begin{array}{l}0.003 \\
(0.09)\end{array}$ \\
\hline GROUP & $\begin{array}{c}0.21 \\
(0.37)\end{array}$ & - & $\begin{array}{l}0.31 \\
(0.36)\end{array}$ & - \\
\hline EXPORT & $\begin{array}{l}-0.25 \\
(0.55)\end{array}$ & $\begin{array}{c}0.21 \\
(0.38)\end{array}$ & $\begin{array}{l}-0.22 \\
(0.32)\end{array}$ & $\begin{array}{c}0.14 \\
(0.65)\end{array}$ \\
\hline HI_R\&D & $\begin{array}{l}0.81^{*} \\
(0.37)\end{array}$ & $\begin{array}{l}-0.77 \\
(0.60)\end{array}$ & $\begin{array}{c}0.70^{* *} \\
(0.28)\end{array}$ & $\begin{array}{l}-0.45 \\
(0.65)\end{array}$ \\
\hline LDC_EXP & - & $\begin{array}{l}0.03 \\
(0.46)\end{array}$ & - & $\begin{array}{l}0.10 \\
(0.52)\end{array}$ \\
\hline CAPTIVE & $\begin{array}{l}-0.02 \\
(0.24)\end{array}$ & $\begin{array}{l}-0.17 \\
(0.54)\end{array}$ & $\begin{array}{c}0.02 \\
(0.30)\end{array}$ & $\begin{array}{l}-0.43 \\
(0.61)\end{array}$ \\
\hline PRODCT & $\begin{array}{l}0.26 \\
(0.23)\end{array}$ & - & $\begin{array}{c}0.28 \\
(0.29)\end{array}$ & - \\
\hline AV_RATE & - & $\begin{array}{l}0.04 \\
(0.03)\end{array}$ & - & $\begin{array}{c}0.03 \\
(0.03)\end{array}$ \\
\hline Log(Employ) & $\begin{array}{c}1.56^{* *} \\
(0.68)\end{array}$ & - & $\begin{array}{c}1.30 \\
(0.79)\end{array}$ & - \\
\hline Other instruments & PUBSTAT, YC & UNG & PUBSTAT, YO & $\mathrm{NG}$ \\
\hline R Squared & 0.73 & 0.22 & 0.79 & 0.18 \\
\hline $\mathrm{N}$ & 95 & 95 & 95 & 95 \\
\hline
\end{tabular}

